\title{
Study on Confucianism in Formation of Man's Spirit
}

\author{
Kunming Yao \\ School of Foreign Languages, Daqing Normal University, China
}

Keywords: Confucianism; man's spirit; formation.

\begin{abstract}
From study the general aspect of Confucianism, to explore the core of the Confucianism is "Ren", "The benevolent love people" is the core and foundation of Confucianism. Study Man's Spirit from the main points of Confucianism. Understanding by Man's spirit in moral values with Confucianism, we can discover that it is not difficult to find the universal significance of personality value. People are the subject of value, they have some demand for personality; personality is the object of value, it has the attribute which can satisfy people's needs. Personality value just exists in the relationship between people and personality. In Confucius's opinion, to govern the country, the rulers must establish the political credit and it is directly related to the effect on handling government affairs.
\end{abstract}

\section{General Introduction of Confucianism}

The interpretation of "Confucianism" in Shuowenjiezi is, " Confucianism ,also known as warlock, whose character is very soft, and they always follow others." In ancient Chinese society, the core of Confucianism are Ren, Yi, Li, Zhi, Xin, Shu, Zhong, Xiao, Ti. This is the traditional interpretation for personality, which interprets the meaning of personality value from each aspect of the spiritual realm. Ren, means love, and is also the core of the Confucianism theory system. It is the highest ideals and standard of Confucius social politics and ethics, and reflects his philosophical opinion as well. Its influence on later generations is profound and lasting. Ren, reflected in the educational thought and practice is "Instruction knows no class distinction". In Spring-Autumn Era, only the patrician can go to study. Confucius started the private school first, and all disciples can be taught without any lot. Benevolence, whose basic spirit essence is universal love for humanity and provide liberal relief to the masses, reflected in politics mainly is "rule of virtue". Confucius cited "Benevolence" into etiquette. Loving humanity is the essential and fundamental content of benevolence, and this kind of love also means "put oneself in others' position", which in other words is to love from the kinsman to the public.

\section{2. "Ren" --- Core and Foundation of Confucianism}

"The benevolent love people" is the core and foundation of Confucianism. Confucius thought the meaning of "Ren" is "A wise man devotes his attention to what is essential in the foundation of life. When the foundation is laid, wisdom will come. Now to be a good son and a good citizen-don't these form a foundation of a moral life? "Kindness loves everyone" means we should treat everyone as families. The specific performance is to put yourself in for the sake of others, "don't do to others what you don't want others to do to you", "put yourself to another's position" and you should help others if you have the ability. The ruler manifests "the benevolent loves people" by having a heart of loving people, applying a policy of benevolence, fighting for the interests of civilian, making people live and work happily, sharing the woe and wealth with people. "Ren" in Confucian School reflects the "love" of people, which means loving oneself, loving others and loving community that a modern society promotes and encourages to. Reading The Analects of Confucius, I found "kindheartedness" and "honesty" are the core and cornerstone of Confucianism. Confucius explained it clearly: "A disciple of Confucius enquired what constitutes a moral life. Confucius answered, "A man who can carry out five things wherever he may be is a moral man." "What five things asked the disciple."They are", 
replied Confucius, "Earnestness, consideration for others, trustworthiness, diligence and generosity." The Analects of Confucius. Confucius said, "A young man when at home should be a good son; when out in the world, a good citizen. He should be circumspect and trustful. He should be in sympathy with all men, but intimate with men of moral character. If he has time and opportunity to spare, after the performance of those duties, he should then employ them in literary pursuits. "The Analects of Confucius. The kindheartedness which Confucius said is a noble sentiment .But according to mental elements; it is a feeling of loving everyone which comes from the heart. It is critical for rules to win the trust of people at any time." Zi Gong asked Confucius about government. Confucius said: "As long as there is enough food, enough people combat readiness and trust it." Zi Gong asked: "If have no alternative against one's will to remove a, three, first remove which one?" Confucius said: "to remove the arms." Zi Gong asked: "If have no alternative against one's will also remove a, two out of which one?" Confucius said: "Without enough food. Since ancient times, people will die, but without the trust of the people, will not be able to stand." Confucius believed that the survival and development must meet three conditions that are: a strong national defense, adequate food and trust of the people of the upper and lower.

Confucius thought "Ren" means "loving people". The view of Confucius comes from the idea of "protect and respect people"

\section{Confucianism and Man's Spirit}

Yi, which refers to the original "suitable" means to be suitable for "ritual behavior". Confucius regards "Yi" as the moral principles to judge people's thought and behavior.

$\mathrm{Li}$, the political and ethical category of Confucius and Confucianism. In the long run of history, as the ethics and living standard of Chinese feudal society, "Li" played an important role in cultivating the spirit of quality of the Chinese nation, but with the development and change of the society, especially in the later period of feudal society, it has more and more become a rope which shackles people's thought and behavior,and also impacts the social progress and development.

Zhi, the same as "know", the basic category of epistemology and ethics, refers to know, understanding, opinion, knowledge, intelligence, wisdom and so on. Its connotation mainly involves some aspects of the property, origin, content, effect of knowledge. On the nature of knowledge, Confucius thought, "knowledge is a moral category, and a normative knowledge for human behavior."

Xin, the attitude towards contacting with people with honest and deeds accord with words, is one of the Confucianism five constant virtues. Confucius regards "Xin" as an important embodiment of Ren, and it is the essential character of virtuous and talented person. One whoever is authentic in his speech and behavior will be able to obtain the trust of others. Authorities keep their words, and people will return honest.

Shu, don't do to others what you don't want others do to you, and it includes forgive and forget.

Zhong, if you want others treat you in the way you want, you must do it first. Confucius thought, "loyalty is embodied in honesty between people."

Xiao, Confucius thought, filial piety is the basic of benevolence. Filial piety is not limited to supporting parents, but should focus on respect to parents and elders. Confucius thought those who lack of filial piety are unfilial, and they regard supporting parents as feeding dogs. Confucius also believed that parents may have been at fault, but children should advise politely, and strive to help them correct, not to obey parents absolutely. These thoughts are just about the reflection to the ancient Chinese moral civilization. Confucius talked about filial piety, however, Confucius remarked, "While his parents are living, a son should not go far abroad; if he does, he should let them know where he goes", "A son who does not change his father's principles for three years in his own life after his father's death ,may be considered to be a good son." These reflect the limitation of the times.

$\mathrm{Ti}$, the love and respect between brothers. Confucius attached great importance to its character, and his disciple Youruo combined it with Xiao, which was regarded as the "basic of benevolence" according to Confucius's thought. 


\section{Value of Confucianism in Universal Significance of Personality}

Understanding by Man's spirit in moral values with Confucianism, we can discover that it is not difficult to find the universal significance of personality value.

The so-called personality (which can be said in other words, such as, personality moral integrity, human dignity) is also known as individuality, and it is a kind of self-consciousness and self-control, and it is the body that has functions of feeling, emotion, volition and other functions. It can depart from the body and people's material living conditions. It refers to the unique and stable thinking and behavior style that can be distinguished from others. Personality is the overall mental outlook, and the sum of a certain tendentiousness and relatively stable characteristics of the psychology.

Personality has different meaning in different situations, so it has extraordinary significance to improve the human nature by understanding the real meaning of it. However, the word personality has the great importance which is related to the nature of man no matter in the common sense, the sense of psychology or the legal sense. In the field of Chinese philosophy, philosophers think that people should show up an image of perfect personality, and a person ends his life in satisfactory by shaping a perfect personality image. Personality is not only in the common sense, or in the psychological level, but also in the theoretical level. An accomplishment of personality is also the accomplishment of the argumentation.

Value is the essence of the existence and development of human. All human self-liberation behaviors are the essence of self-preservation and development in all the human practice. The value has specific forms in many fields, such as, social value, individual value, economic value, legal value, and so on. These values' existence are the essential existence of category and the regularity of human development in different fields. All development that people create for self-world is valuable.

Personality value is able to meet the needs of people's qualifications on the subject itself in practice. Personality value is in proportion to the value that man creates. The activity of people creates value subjects to the development level of social productivity and the social system. In aspects of personality value affiliation, Record of Rites has these proposals: on the one hand, it emphasizes "try one's best", "pull out", "be relieved", "be modest", "be sincere"; on the other hand, it emphasizes people should keep ritual and moral. "We should be obedient to ourselves inside, and be obedient to moral outside" is the interpretation of attribute value in Record of Rites. The essence trait of personality value is the unity of subjectivity and sociality. Goodness is an important concept in The Great Learning, and it is the condition that enables us to realize the personality value. Goodness actually is the doctrine of the mean thought. Personality value is not a passive finish but an active creation, and an existence tends to the goodness. It is not the complement of value of itself, but the complement together between others and oneself. It is the integration of "pleasant virtue" and "new man". "Be obedient to self-inside" refers to trying best in heart, and "Be obedient to moral outside" refers to conform the social regulation. That is just in accord with the form of personality value.

The Doctrine of the Mean said," It is only the man with the most perfect divine moral nature that is able to combine in himself quickness of apprehension, intelligence, insight and understanding: qualities necessary for the exercise of command; magnanimity, generosity, benignity and gentleness: qualities necessary for exercise of patience; originality, energy, strength of character and determination: qualities necessary for the exercise of endurance; dignity, noble seriousness, order and regularity: qualities necessary for the exercise of critical judgment." The five aspects above are the descriptions for the realm of personality of sage, which relates to aspects of people's wisdom, emotion, and comprehension, and it is the highest tidemark of personality value.

\section{Conclusion}

The scholars of Confucianism have always attached the importance to integrity and fully believed in "I do not know how men get along without good faith." "Make conscientiousness and sincerity your first principles" "Act up to what is right. In that way you will raise the moral sentiment in you." "One who makes it a point to carry out what he says and to persist in what he undertakes." Confucius originated Xin as an ethical-sociopolitical teaching and took it as the thought of Five Virtues with 
Gong, Kuan, Min and Hui. The Analects of Confucius said: "There are four things which the Master taught: letters, ethics, devotion of soul, and truthfulness." The scholar Mencius taught the relations of humanity: how, between father and son, there should be affection; between sovereign and minister, righteousness; between husband and wife, attention to their functions; between old and young, a proper order; and between friends, fidelity. He regarded "the fidelity between friends" of these five social relationships as basic norms of morality. The Book of Mencius said: "Sincerity is the way of Heaven. To think how to be sincere is the way of man." Therefore, honesty and creditability plays as traditional content of moral principles.

Confucianism stresses "the people have no faith cannot stand", and so does it in running a country. In Confucius's opinion, to govern the country, the rulers must establish the political credit and it is directly related to the effect on handling government affairs. When erecting political credit, people are willing to believe their own rulers, which will also help them to consolidate their domination. To sum up, Xin is to guarantee the authenticity of their commitments, which should be complied with, whether in hierarchical relationships or social behavior.

\section{References}

[1] Kongzi. Lunyu [M]. Beijing: Huaxia Press, 2017

[2] Montesquieu. The Spirit of Law [M]. Bejing: People's daily press, 2008

[3] Rujia Four Books and Five Classic[M]. http://t.icesmall.cn/novel/post/10.html

[4] Song hongde, Li-xue Gai, Ma Yinlin, The Iron Man Spirit [M]. Harbin: Heilongjiang people's Publishing House, 2009

[5] Sun Baofan, Lu Zezhou, The Iron Man Biography [M]. Bejing: The Central Literature Publishing House, 2009 